\title{
Role of Local Government and MSMEs Performance: The Case of Ethiopia
}

\author{
Kataro Galasso Gamo $P h D$ \\ Assistance Professor \\ College of Engineering \\ Wolaita Soddo University \\ Wolaita Soddo, Ethiopia \\ E-mail: katarogal@yahoo.com \\ Ramakrishna Gollagari PhD \\ Professor \\ College of Finance, Management and Development \\ Ethiopian Civil Service University \\ E-mail: profgrk@gmail.com
}

\begin{abstract}
Micro, small and medium enterprises (MSMEs) are one of the important sectors in both developed and developing countries contributing to economic growth and poverty alleviation. They play a significantly important role in contributing to economic growth, with a major share of employment in Ethiopia. However, in purposively selected three Urban Administrations under the study, the sectors are not playing their essentially expected roles. This study, therefore, examined the role of local government in supporting MSMEs performance. The study employed a mixed method approach using both quantitative and qualitative data. Data required for the study are gathered from secondary and primary sources. Secondary source data are gathered from books, journals, and related earlier research outputs as well as from the regional, zonal and administrative towns archival. Primary data are gathered from extensive field works through a questionnaire survey, key informant interviews, and personal observations by employing structured and unstructured questionnaires. The sample population is identified using stratified sampling design, thus, 54I samples are identified. Furthermore, 22 enterprise owners/managers were identified purposively as a target sample for key informant interviews. Document analysis, narrative analysis, and descriptive statistics have been used to analyze the data. The findings of the study indicated that, low level of employment and capital generation of MSMEs due to ineffective local government support. This study is important to attract investment and enhance the performance of the businesses in the local area. In general, this study will be significant to enhance the economic growth of the region by creating employment to reduce the heavy burden placed on larger cities by accommodating the ever-increasing population of the region. Therefore, local government institutions should create a conducive local business environment to attract more investment and promote the existing firms' performance.
\end{abstract}

Keywords: MSMEs, Performance, Local Government Support, Urban Centers, Wolaita.

\section{Introduction}

The decentralization of government bestowed on local government's new roles, powers, and responsibilities, including the role of enabling the local business environment to attract investment and enhance the performance of existing firms. This is particularly true in Ethiopia where decentralization in its various forms has been an integral part of government reforms starting from the $200 \mathrm{I}$ local government code. The government's underlying principle for decentralization has been the accommodation of ethnic pluralism and empowerment of Nations, Nationalities, and peoples in the country (Zemelak, 20I I). According to Zemelak, the federal system of government devolved powers to ethnic groups at the regional state level. The ethnic-based regional states were responsible for the country's political, administrative, economic, and social objectives (Tsegaye, 2006).

Despite some successes in the first phase of ethnic decentralization for citizens participation, the local governance dynamics within Ethiopia's regions were challenged by the low level of power transferred, limited managerial and technical capacity, and the political, administrative and fiscal subordination of local governments to higher levels of governments (Meheret, 2007). According to Meheret (2007), the intended targets for transformed local government and improved Public service provision had been missing targets. In order to address the aforementioned problems, as the second phase of decentralization, District level decentralization program was publicized to "shift decision-making closer to the people at the Zone, District, and Kebel levels" (Dickovick and Tegegne, 2010). It was intended to "empower Districts, make local governments responsive for and accountable to citizens, strengthen public participation and consultation at the grassroots level, 
and to improve local government transparency (Meheret, 2007). Particularly, it aims to promote public trust mainly through empowering local government units to enable their local area favorable to business attraction and performance to enhance economic development.

In this phase, the Federal Democratic Republic of Ethiopia (FDRE) government has embarked on sequences of "political, legal, fiscal and administrative changes rapidly in 2002" (PSCAP Report, 2008). All the local governments have given responsibility to create enabling business environment in their locality to attract new business and to enhance the performance of the existing businesses. Based on this decentralization program, all the development policies and strategies crafted at the federal level were cascaded at the local levels. For example, one of the strategies that were crafted at the federal level was the new micro and small enterprise development strategy (20II). According to the MSEs Strategy document of 20II, the strategy devises not only reducing poverty through employment in urban areas but also nurturing entrepreneurship and laying the foundation for industrial development by the transition to medium size level enterprises (FMSEDA, 20II). Based on the strategy the regional governments of the FDRE have entitled to cascade the strategy and implement at the zonal and district/urban levels.

Nevertheless, in the case of Wolaita Zone, MSMEs are not well performing to discharge their expected roles in employment creation and in absorbing rural surplus labor migrating to zonal urban centers due to different internal and external factors. According to the report of Wolaita Zone Youth and Sports Department (WZYSD), 32\% of the youth are unemployed (WZYSD, 2017). Tantu, et al. (2017) in their paper have examined household food insecurity and associated factors among households in Wolaita Soddo town. The result shows that 36.7 percent of the surveyed households in Wolaita Soddo town are food insecure. The authors also show that household food insecurity is high in the study area compared to the urban national average of Ethiopia. Leza et al. (2017) showed that MSEs at Wolaita Zone continue to be capital-starved and remain low in their job creation potential. The study also indicated that the zone has not yet exploited their potential very well to contribute towards economic development, job creation, and poverty reduction. To solve these problems, promoting MSMEs has become a preferred development strategy in the zone. Therefore, this study sought to examine the local government and institutions support in attracting and enhancing firms' performance in the three selected administrative towns of Wolaita zone.

\section{Literature Review}

In a decentralized system of government as in Ethiopia, local governments exercise considerable autonomy, as well as various roles and functions intended to increase accountability and responsiveness of government services to local performances (Roxas, et al., 2009). They are expected to assume a leading role in a local economy by developing various forms of interventions to attract business to invest in the local area and enhance the performance of the existing firms. The government support policies for MSMEs vary from country to country and from developed economies to developing nations due mainly to the level of industrialization, cultural differences and business context (Ibrahim, et al. 2016). Governments of most countries, especially developing countries have invested so many efforts and resources in establishing policies geared toward improving entrepreneurship and MSMEs (Quy, 2016; Shariff et al., 2010). However, previous studies indicated that overall government supports for SMEs are not impressive in Sub-Saharan Africa including Ethiopia, in cases where such programs exist, they are under-utilized (Fatoki, 2012).

In Ethiopia, the incumbent government has geared its efforts towards the development of MSMEs. Several policy measures and financial support instruments were introduced. The government over the years demonstrated its commitment to support the development of MSMEs through various initiatives including financial and industrial policy measures (MoUDC, 20I3). In addition to this, urban development policy, industry development strategy and both the old and new Micro and Small Enterprises Development Strategies of the government show the supports enterprises receive from local government bodies have a role on their performance. However, such government incentive initiatives were not yielding the desired result due to overbearing bureaucratic procedures, corruption, insufficient and ineffectual infrastructural amenities, and inconsistent government policies as some of the challenges faced by MSMEs in Ethiopia (MoUDC, 20I3; Assefa, et al.,20I4).

Assefa et al. (2014) argued that even though Ethiopian want to be more business oriented; the government is not doing enough to encourage them through incentives and support policies. The government should endeavor to provide an enabling environment for private sector-led entrepreneurship through the delivery of suitable and functional infrastructural amenities (Assefa et al.,20I4; MoUDC., 2013; Fikadu, 20I5). The SMEs sector does not only boosts the entrepreneurial activity but also generates a huge portion of a nation's employment, create income, reduce poverty level, the source of innovation and hence new products and service development (Fikadu, 20I5; MoUDC, 2013; Brhane, 20I4). As such, MSMEs needs support from the government in the areas of trade promotion, marketing research expansion, and financial policies. Furthermore, institutional support for SMEs should include the five key sectors such as finance, legal corridors, investment and development in technology, information and consultation and market promotional expansion (Quy, 20I6; Shariff et al., 20I0).

The systematic literature survey conducted by the researchers revealed that no study has been undertaken so far in the study area to examine the role of local government support enhancing MSMEs performance. Based on these facts, this paper examined the contribution of local government in supporting firms' performance. In order to assess the effectiveness of the local 
government and institutions support to SMEs, we examine whether the provision of finance; working promises; infrastructure and services; market linkages; management; and institutions are examined with respect to enhancing business performance.

\section{Research Methodology \\ 3.I Study Area}

Wolaita Zone is one of the 18 Zones including Hawassa Town Administration in the Southern Nations Nationalities and Peoples Regional State. The Zone has I6 rural districts and 6 Town Administrations including the three sampled towns Wolaita Soddo, Areka and Boditi (WZFEDD, 2018). According to the Central Statistical Authority (CSA, 2007) estimated population projection of the Zone is I,907, 804 in 2015 (WZFEDD, 2017). The total area of the Zone is 45I,I70 hectare or 4,5II.7 kilometers square. The population density of the zone is 445 persons per kilometer square. The average urban household size was 4.8 , while the total zonal population growth rate is one of the fastest in the region with an average of about $2.8 \%$ (WZFEDD, 2017). The zone has 2548 micro and 192 small enterprises established during 2005-20I3 that include all economic sectors (Leza, et al., 2017). According to the authors, the sectors composed of 357 (I3.I\%) manufacturing, 8I4 $(29.7 \%)$ construction, $748(27.3 \%)$ trade, 612 (22.3\%) services and 209 (7.6\%) urban agriculture. These sectors created I6,I9I employment opportunities for the people of the Zone (Leza, et al., 20I7). In the three sampled Administrative Towns there are 1978 MSMEs in four sectors (Manufacturing, trade, service, and construction) (WZFEDD, 2018).

\subsection{Study Population and Sampling Technique}

The study population for this research was MSMEs in the three administrative towns (Wolaita Soddo, Areka, and Boditi) in Wolaita Zone. There are 1978 MSMEs in the three sampled towns. Stratified sampling technique was employed to select representative samples by using the stratification variables such as town, size, and sector from MSMEs. The minimum number of MSMEs that need to be included in the sample is determined using the following formula (Cohran, I963 cited in Kothari, 2004):

$$
\mathrm{n}=\frac{\mathrm{Z}^{2 \times x} \mathrm{P}(\mathrm{I}-\mathrm{P})}{\mathrm{e}^{2 \times}\left[\mathrm{Z}^{2} \mathrm{P}(\mathrm{I}-\mathrm{P})\right] / \mathrm{N}} \quad 54 \mathrm{I}
$$

Where: $\mathrm{n}=$ sample size required; $\mathrm{N}=$ Number of sampling target population $=1978$; $\mathrm{e}=$ margin of error $=0.0365(3.65$ per cent). The proportion of $\mathrm{p}=65$ percent refers to the threshold that distinguishes between effective and ineffective MSMEs. As indicated by extant literature small businesses are heterogeneous, it requires a large sample size to obtain the desired precision level. Therefore, by using the margin of error 3.65 percent the sample size becomes 54I to avoid non-response problem and sample size error (Ibrahim and Sharif, 2016).

\subsection{Data Sources and Methods of Data Collection}

Both quantitative and qualitative data were collected from primary and secondary sources. Quantitative data were collected from 54I MSME owners/managers through a questionnaire survey and 22 key informant interviews from MSME owners/managers. Secondary source data are gathered from books, journals, and related earlier research outputs as well as from the regional, zonal and administrative towns archival, libraries of academic institutions and the like.

\subsection{Method of Data Analysis}

The study employed document analysis for secondary data, narrative analysis for key informant interview, and descriptive statistics for data collected through a quantitative questionnaire survey.

\section{Results and Discussions}

\section{I Socio-Economic and Demographic Characteristics}

The study was conducted to determine the role of local government in supporting MSMEs performance in selected administrative towns of Wolaita Zone. A total of 54I MSME owners/managers participated in this study, however, I6(3\%) questionnaires were discarded with the response rate of $97 \%$ used for the analysis. The data revealed that $73.3 \%$ of the respondents were male, $95.8 \%$ were under 40 years old, most of the owners/managers were literate and have business experience, and $33.7 \%$ were from trade sector.

Table I. Socio-economic and Demographic Characteristics of the Respondent

\begin{tabular}{|c|c|c|c|c|}
\hline Variable & $\mathrm{N}=525$ & Category & Frequency & Percentage \\
\hline \multirow{3}{*}{\multicolumn{2}{|c|}{ Location Town }} & Wolaita Soddo & 295 & 56.19 \\
\hline & & Areka & 146 & 27.81 \\
\hline & & Boditi & 84 & 16.00 \\
\hline $\begin{array}{l}\text { Sex } \\
\end{array}$ & & Male & 385 & 73.33 \\
\hline
\end{tabular}




\begin{tabular}{|c|c|c|c|}
\hline & Female & $\mathrm{I} 40$ & 26.67 \\
\hline \multirow[t]{4}{*}{ Age of Owners/Managers } & I5-20 & 9 & 1.7 \\
\hline & $2 I-30$ & 335 & 63.8 \\
\hline & $3 I-40$ & 159 & 30.3 \\
\hline & $4 \mathrm{I}-50$ & 22 & 4.2 \\
\hline \multirow[t]{8}{*}{ Educational Level } & Illiterate & $\mathrm{I}$ & .2 \\
\hline & Read and Write & $\mathrm{I}$ & .2 \\
\hline & $\mathrm{I}-4$ & 5 & .9 \\
\hline & $5-8$ & 36 & 6.9 \\
\hline & $9-10$ & 179 & 34.1 \\
\hline & II-I2 & 84 & I6.0 \\
\hline & Diploma & 159 & 30.3 \\
\hline & Degree and above & 60 & II.4 \\
\hline \multirow[t]{4}{*}{ Sector } & Manufacturing & $\mathrm{I} 58$ & 30.1 \\
\hline & Trade & 177 & 33.7 \\
\hline & Service & II8 & 22.5 \\
\hline & Construction & 72 & 13.7 \\
\hline
\end{tabular}

\subsection{Performance of MSMEs}

\subsection{Employment Generation}

The survey results show that $73.33 \%$ of firms in the study had less than six persons in employment, $20.19 \%$ had six to ten persons in employment, $4.38 \%$ of the firms had employed eleven to fifteen employees, $1.53 \%$ had sixteen to twenty employees and $0.57 \%$ had more than 30 persons in employment. The result indicates that most of the businesses are under micro enterprises category and it is necessary to promote more small and medium-sized firms. Regarding employment size in the sector, $30.28 \%$ of microenterprises were from the trade sector, $17.9 \%$ from the service, $17.71 \%$ from the manufacturing and $7.43 \%$ from the construction sector. Medium size in employment was only from the manufacturing and construction sectors $0.38 \%$ and $0.19 \%$ respectively. Concerning the number of employees per sector, the construction sector has the highest average number of employees (8.32) followed by manufacturing (6.19). The minimum number of employee is I in manufacturing, trade and service sectors, while the maximum number of employee is $6 \mathrm{I}$ in manufacturing followed by 44 in construction.

In the finding, $73.33 \%$ of firms created employment for less than or equal to five workers confirms that more small and medium-sized enterprises are needed to make appreciable impacts on employment. The qualitative informant interview result indicates the reasons behind weak performance of MSMEs in administrative towns such as the provision of physical infrastructure, financial access, and the unfavorable business environment was fully blamed on local governments for not doing enough to enhance their performance. Table 2 presents the employment generation of sampled firms in administrative towns.

Table 2. Employment Created by MSMEs in Sector in Administrative Towns

\begin{tabular}{|c|c|c|c|c|c|c|c|c|c|c|}
\hline \multirow[t]{2}{*}{ Employment Size } & \multicolumn{2}{|c|}{ Manufacturing } & \multicolumn{2}{|c|}{ Trade } & \multicolumn{2}{|c|}{ Service } & \multicolumn{2}{|c|}{ Construction } & \multicolumn{2}{|c|}{ Total } \\
\hline & No. & $\%$ & No & $\%$ & No & $\%$ & No & $\%$ & No & $\%$ \\
\hline $\mathrm{I}-5$ & 93 & I7.7I & 159 & 30.28 & 94 & 17.90 & 39 & 7.43 & 385 & 73.33 \\
\hline $6-10$ & 53 & 10.09 & I6 & 3.05 & 23 & 4.38 & I4 & 2.67 & 106 & 20.19 \\
\hline II-I5 & 10 & 1.90 & 2 & 0.38 & - & - & II & 2.09 & 23 & 4.38 \\
\hline $16-20$ & - & - & - & & $\mathrm{I}$ & 0.19 & 7 & 1.33 & 8 & 1.53 \\
\hline 3I and above & 2 & 0.38 & - & - & - & - & $\mathrm{I}$ & 0.19 & 3 & 0.57 \\
\hline Mean & 6.16 & & 4.37 & & 4.61 & & $3 \mathrm{I}$ & & & \\
\hline S. D & 5.56 & & I.89 & & 2.09 & & 08 & & & \\
\hline Min & 1.00 & & 1.00 & & 1.00 & & 0 & & & \\
\hline$\overline{\operatorname{Max}}$ & $6 \mathrm{I}$ & & $\mathrm{I3}$ & & I7 & & 4 & & & \\
\hline Total & $\mathrm{I} 58$ & 30.09 & $\mathrm{I77}$ & $33.7 \mathrm{I}$ & II8 & 22.48 & 72 & I3.7I & 525 & 100 \\
\hline
\end{tabular}

In an attempt to investigate whether or not MSMEs are growth-oriented or survivalists in generating employment opportunities, the study asked the respondents to indicate their firms' trend in the generation of employment for the last three years. About 29.7\%, 58.1\% and 12.2\% of micro, small and medium enterprises reported as growing, stagnant and declining, 
respectively. In the administrative towns, the self-reported proportion of stagnant firms is very high, but the share of firms that reported a declining performance is lower compared with increasing growth performance enterprises. Figure.I shows the selfreported growth performance of MSMEs.

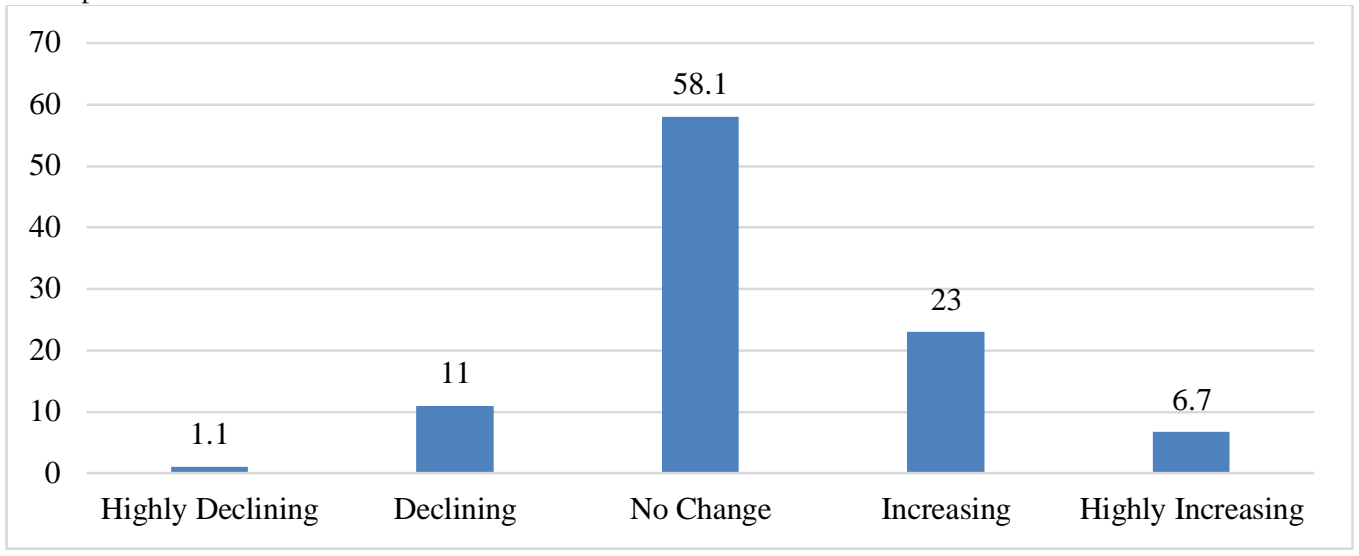

\subsubsection{Profitability of MSMEs}

Figure I. Self-Reported Growth Performance of MSMEs

Regarding the profitability of micro, small and medium enterprises, the result of the respondents indicated that $59.6 \%$ of the firms were profitable, $23 \%$ of the firms were not profitable and $17.3 \%$ were indicated that they were yet identified whether the firms were profitable or not.

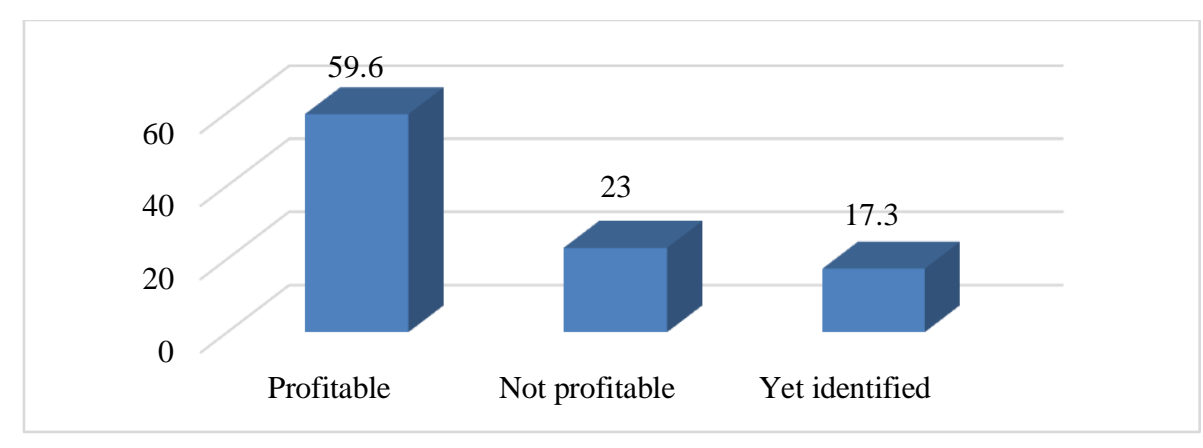

Figure 2. Profitability of Enterprises

Figure 2 shows that $59.6 \%$ of the sampled owners/ managers of MSMEs were profitable. The study also posed a question that how much of the profit they change into investment. Regarding changing profit to investment, Table 3 displays that $21 \%$ converted half of their surplus to investment, $46.7 \%$ less than half of their profit into investment. However, $9.3 \%$ indicated no surplus converted.

Table 3. Sample MSMEs Owners/Managers Position of Changing Profit to Investment

If your firm is profitable, what proportion of your surplus do you regularly convert to investment?

\begin{tabular}{lccc}
\hline & Frequency & Percent & Cumulative Percent \\
\hline Not Profitable & 121 & 23.0 & 23.0 \\
\hline At least half of my surplus converted & 110 & 21.0 & 44.0 \\
\hline Less than half of my surplus converted & 245 & 46.7 & 90.7 \\
\hline No surplus converted & 49 & 9.3 & 100.0 \\
\hline Total & 525 & 100.0 & \\
\hline
\end{tabular}

Dardak (2007) points out the early theories of economic development, which include the linear stages of growth, emphasizing the importance of savings in economic development. According to Dardak, these theories may be outdated, but the 
role of saving and investment as drivers of growth has never been contested. Therefore, unless owners/managers in small and medium towns can generate savings from the surplus of their produce, the extent of growth for the locality will depend on the mercy of external investors. Government intervention in redistributing investment returns through taxation or incentives to local entrepreneurs through microfinance seems to be a feasible policy option in creating a desirable development in small and medium urban centers.

\subsubsection{Export Performance of MSMEs}

Regarding the performance of MSMEs in exporting, this study asked respondents if their firms export their products. From a total of 525 respondents, only $3(0.6 \%)$ reported that they export their product. The remaining 522 (99.4\%) are not exporting. Figure 3 presents responses of the owners/managers concerning exporting.

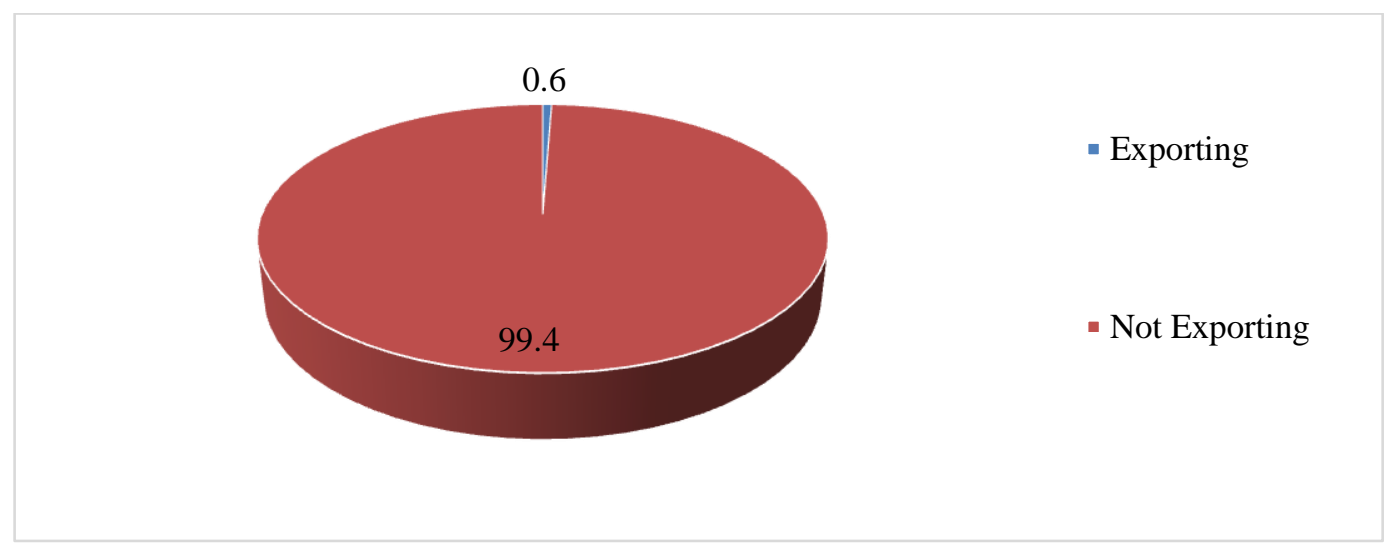

Figure 3. Exporting Situation of Firms in the Zone

Based on the qualitative data from key informants interview of 22 selected MSME owners/managers from the three administrative towns, all the participants of MSMEs reported that they are not exporting their product. In addition to primary data, the secondary data from the CSA report (2012) the overall export performance of the manufacturing sector (2006-2010) decreases from I.2 million in 2006 to 0.6 million in 2007 and increase to I.3 million in 2008. It also indicates a continuous decline rate from 2008 to 20I0, which is I.3 million in 2008 to I.I million in 2009 and I.0 million USD in 2010.

Both the quantitative and qualitative data results show most of the firms are not exporting. This finding implies that the firms were engaged in providing their product or services to the local market, thereby not contributing to export earnings. This result has implication for the need for local government and private sectors have to focus on agriculture to expand exportoriented small and medium manufacturing and boost exports. This result corroborates the finding of Legesse (20I4) for medium and large industries in four industrial zones of Ethiopia for low export performance.

\subsubsection{Dynamics of Micro, Small and Medium Enterprises}

Dynamics of small businesses measured in terms of net expansion that arises from net entrants and net expansion from the growth of existing firms (Liedholm, 2002). Liedholm finding indicates that the firm's expansion from existing firms has contributed more to the overall expansion in the size of small businesses than the net new firm's addition. Garoma (2012) also relied on this methodology to find the dynamics of microenterprises in Addis Ababa. This study also relies on this methodology and identifies the dynamics observed between the firm establishment and the time of data collection.

Following Liedholm (2002) and Garoma (2012), both the performance indicators were measured by averaging the yearly growth rates. The firm's first appearance in the data set is taken as the base year for computing growth rates as advocated for example by Dunne, et al. (I989). Thus average annual growth rate for both performance indicators is calculated using the following formula:

$\mathrm{G}=[$ (current size - size at establishment)/size at establishment $] /$ firm age

Where, $\mathrm{G}=$ average annual growth rate for both indicators, current size represents real values for current capital and employment size on the data collection time, size at establishment represents real values for both capital and employment size on the time of establishment, firm age is the time (in year) elapsed between the time of establishment and the data collection time. Table 4 below displays the summary of enterprises' average annual growth rates for capital and employment respectively. According to the data, about $0.76 \%$ faced negative annual capital growth and $12.57 \%$ of the MSMEs have cut jobs/reduced employment. About $69.52 \%$ of the firms show 0 to 10 percent growth rate in employment, $6.86 \%$ show II -20 , $4.95 \%$ show 
2I-30, 2.29\% show 3I-40, I.33\% show 4I-50 and I.I4\% show 5 I-50 percent growth in employment. The remaining I.33\% showed more than 60 percent growth in employment. Concerning capital growth, Table 4 reveals that $0.76 \%$ show reduction in capital, $12.38 \%$ showed 0-I0 percent growth, 7.62\% showed II-20 percent growth, 4.57\% showed 2I-30 percent growth, $5.52 \%$ showed 3I-40 percent growth and 4.38\% showed 4I-50 percent growth in capital. Table 4.33 also revealed that $47.24 \%$ of firms show more than 100 percent growth in capital.

Table 4. Average Growth Rates of Performance Indicators of MSMEs

\begin{tabular}{|c|c|c|c|c|}
\hline \multirow[t]{2}{*}{ Average Growth Rate Category } & \multicolumn{2}{|c|}{ Capital Growth } & \multicolumn{2}{|c|}{ Employment Growth } \\
\hline & $\bar{f}$ & $\%$ & $\bar{f}$ & $\%$ \\
\hline$<0$ & 4 & 0.76 & 66 & $\mathrm{I} 2.57$ \\
\hline $0-10$ & 65 & 12.38 & 365 & 69.52 \\
\hline II -20 & 40 & 7.62 & 36 & 6.86 \\
\hline $2 \mathrm{I}-30$ & 24 & 4.57 & 26 & 4.95 \\
\hline $3 \mathrm{I}-40$ & 29 & 5.52 & $\mathrm{I} 2$ & 2.29 \\
\hline $4 \mathrm{I}-50$ & 23 & 4.38 & 7 & $\mathrm{I} .33$ \\
\hline $5 I-60$ & 16 & 3.05 & 6 & I.I4 \\
\hline $6 \mathrm{I}-70$ & 24 & 4.57 & 2 & 0.38 \\
\hline $7 \mathrm{I}-80$ & 14 & 2.67 & - & - \\
\hline $8 I-90$ & I5 & 2.86 & 2 & 0.38 \\
\hline 9I-I00 & 23 & 4.38 & - & - \\
\hline$>100$ & 248 & 47.24 & 3 & 0.57 \\
\hline
\end{tabular}

It is a comparable proportion (47.24\%) in the capital and only $0.57 \%$ in employment registered a more than $100 \%$ real annual growth. Moreover, the balance has registered a positive capital and employment growth of less than I00\%. Hence, it can be seen from the table that the majority (69.52\%) have registered 0 to $10 \%$ growth in employment, however, $47.24 \%$ have registered more than $100 \%$ capital growth during their operation period. Accordingly, most of the businesses have their capital increasing showing their capacity to raise the number of workers in their firms. However, this finding clearly shows that the growth of capital of firms not resulted in employment growth. This implies that MSMEs in the administrative towns gave more emphasis to capital growth than employment growth.

\subsubsection{Business Performance Defined by Owners/Managers Perception}

Table 5 reveals that from total 525 sampled respondents $265(50.6 \%)$ of the respondents reported their disagreement or strong disagreement for the statement the number of employees in their firm has been increasing for the last three years. The result also revealed that I85 (35.3\%) indicated their agreement or strong agreement by the statement. Regarding profitability, 55.6\% of the 525 respondents either agree or strongly agree with the statement "our business has been profitable over the last three years". However, $56.2 \%$ of the respondents either disagree or strongly disagree with the statement "our business performance has been very satisfactory". Therefore, the findings indicate that most of the respondents show either their disagreement or strong disagreement about five of the performance measurements.

Table 5. MSME Owners'/Managers' Opinion on the Business Performance

\begin{tabular}{|c|c|c|c|c|c|}
\hline \multirow[b]{2}{*}{$\begin{array}{l}\text { Agreement/ } \\
\text { Disagreement }\end{array}$} & \multicolumn{5}{|l|}{ Items } \\
\hline & $\begin{array}{l}\text { Our business has } \\
\text { been Profitable } \\
\text { over the last } 3 \\
\text { years }\end{array}$ & $\begin{array}{l}\text { Our firm has generated a } \\
\text { high volume of sales in } \\
\text { the last } 3 \text { years }\end{array}$ & $\begin{array}{l}\text { The number of employees } \\
\text { in our firm has been } \\
\text { growing over } 3 \text { years }\end{array}$ & $\begin{array}{l}\text { Our business } \\
\text { fully met our } \\
\text { expectations }\end{array}$ & $\begin{array}{l}\text { Our business } \\
\text { performance has been } \\
\text { very satisfactory }\end{array}$ \\
\hline S. Disagree & 8.4 & 8.8 & 13.5 & 18.7 & 19.6 \\
\hline Disagree & 17.0 & 28.8 & $37 . I$ & 37.7 & 36.6 \\
\hline No comment & 19.0 & 19.6 & I4.I & 13.9 & $\mathrm{I} 2.4$ \\
\hline Agree & 50.1 & 34.9 & 26.3 & 23.6 & 26.1 \\
\hline
\end{tabular}




\begin{tabular}{|c|c|c|c|c|c|}
\hline S. Agree & 5.5 & 8.0 & 9.0 & 6.1 & 5.3 \\
\hline Mean & 3.27 & 3.05 & 2.80 & $2.6 I$ & $2.6 \mathrm{I}$ \\
\hline Median & 4.00 & 3.00 & 2.00 & 2.00 & 2.00 \\
\hline Mode & 4.00 & 4.00 & 2.00 & 2.00 & 2.00 \\
\hline Std. Deviation & 1.07 & I.I4 & 1.22 & 1.20 & $\mathrm{I} .2 \mathrm{I}$ \\
\hline Minimum & 1.00 & 1.00 & 1.00 & 1.00 & 1.00 \\
\hline Maximum & 5.00 & 5.00 & 5.00 & 5.00 & 5.00 \\
\hline
\end{tabular}

\subsection{Support of Local Government to MSMEs}

Concerning support given to MSMEs, the sampled owners/managers were asked to indicate whether they got support to enhance their performance. Accordingly, $74.1 \%$ of the respondents indicated that they got support, but the remaining $25.9 \%$ showed no support.

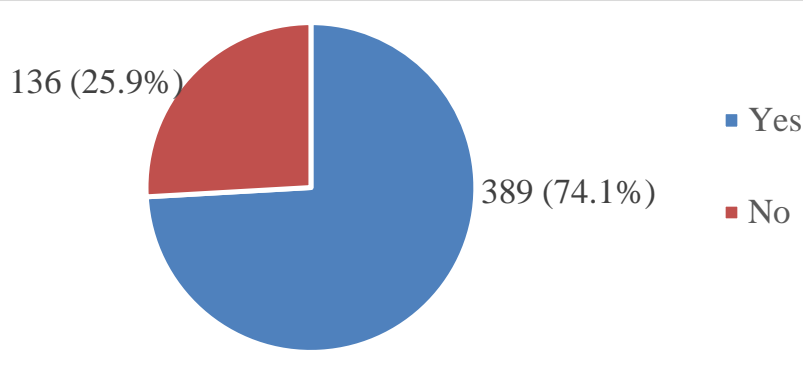

Figure 4. MSME Owners/managers Response about the Support given to the Business

Among 389 or 74.1 percent of total 525 that responded that they got support from the government institutions, 29.5 percent indicated that they got training support, I6.6 percent finance support, I4.3 working premises, and the remaining balance reported market linkages, infrastructure provision and the mix of all supports.

Table 6. MSME owners/managers response for kinds of support they get from government institutions

\begin{tabular}{lccc}
\hline Support & $\mathrm{f}$ & $\%$ & Cumulative \% \\
\hline No Support & $\mathrm{I} 36$ & 25.9 & 25.9 \\
\hline Training & $\mathrm{I} 55$ & 29.5 & 55.4 \\
\hline Finance support & 87 & $\mathrm{I} 6.6$ & 72.0 \\
\hline Market linkages & $\mathrm{I} 2$ & 2.3 & 74.3 \\
\hline Working Premises & 75 & $\mathrm{I} 4.3$ & 88.6 \\
\hline Infrastructure provision & 6 & $\mathrm{I.I}$ & 89.7 \\
\hline Others (Specify) & $\mathrm{I} 2$ & 2.3 & 92.0 \\
\hline Training and Finance support & $\mathrm{I}$ & $\mathrm{I}$ & 93.9 \\
\hline Training and Market linkages & 6 & $\mathrm{I} . \mathrm{I}$ & 95.0 \\
\hline Training and Working Premises & 23 & 4.4 & 99.4 \\
\hline Training, Market linkages, Working Premises, and Infrastructure provision & 3 & .6 & 100.0 \\
\hline Total & 525 & 100.0 & \\
\hline
\end{tabular}


Therefore, based on this fact, the sample MSME owners/managers were asked to indicate the favorability of the local business environment for their businesses. As shown in Figure 5 the majority $(74.1 \%)$ indicated that the favorability of the business environment is low or very low, II\% showed high or very high, while the balance $14.9 \%$ indicated medium.

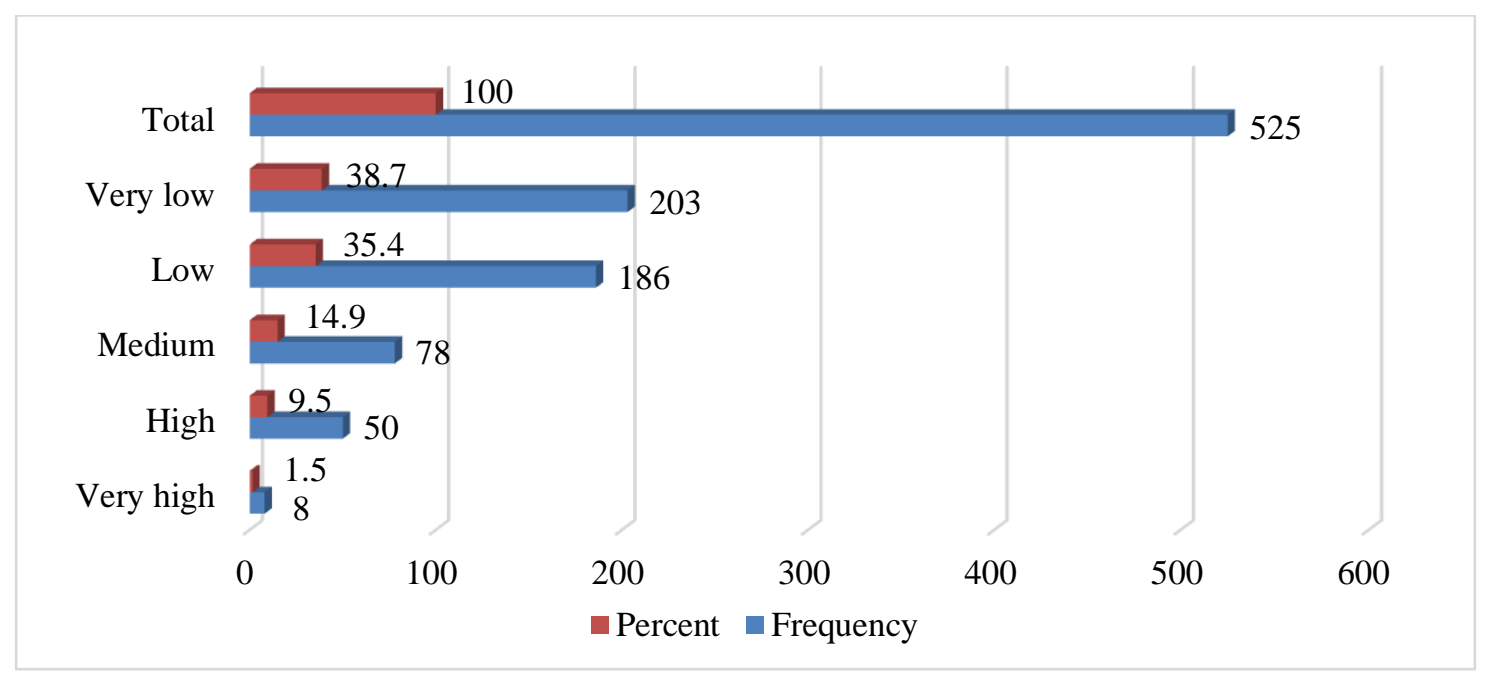

Figure 5. MSME Owners'/Managers' Opinion about the business environment

\subsection{Level of Satisfaction of Respondents at Support Given by Local Government Departments and Institutions}

This study also sought to look at the availability of quality support services being given by the respective local government bodies and institutions by asking their level of satisfaction by the support. Hence, the quality of the support of the offices in three administrative towns, zonal departments, Wolaita Soddo University and the three training institutions in the zone were evaluated based on the satisfaction level of the sampled MSMEs in the administrative towns. This study sought to understand the level of satisfaction of the owners/managers of sampled enterprises regarding the support of a specific sector in the local area, which is assigned to provide the support (Table 7).

Table 7. MSME Owners/Managers Opinion on Support Given by the Local Governments and Institutions

\begin{tabular}{|c|c|c|c|c|c|c|}
\hline \multirow[b]{2}{*}{ Local Government Institution } & \multirow[b]{2}{*}{ 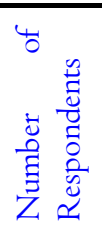 } & \multicolumn{5}{|c|}{ Level of Satisfaction or Dissatisfaction } \\
\hline & & 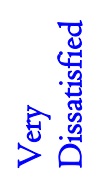 & 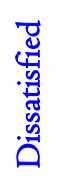 & 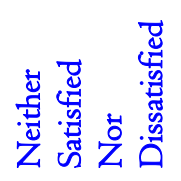 & 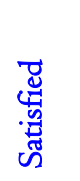 & 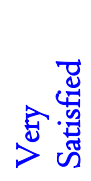 \\
\hline Urban Development and Housing Department & 525 & $2 \mathrm{I} .3$ & 32.6 & $2 \mathrm{I} .5$ & 21.5 & 3 \\
\hline Trade and Industry Department & 525 & I3.I & 37.9 & 19.8 & 25.3 & 3.8 \\
\hline Wolaita Zone Investment Agency & 525 & 16.2 & 35.6 & 28 & 17.7 & 2.5 \\
\hline MSMES Development Office & 525 & II.6 & 27.8 & 18.2 & 39.2 & 6.1 \\
\hline Mayor's Office & 525 & 17.3 & 31.2 & 19.2 & 28 & 4.2 \\
\hline Municipality & 525 & 16.2 & 31.2 & $\mathrm{I} 4.5$ & 32.4 & 5.7 \\
\hline Trade and Industry Office & 525 & I5 & 21.3 & II.6 & 43.6 & 8.4 \\
\hline Tax and Revenue Office & 525 & 32.4 & 30.7 & 10.5 & 22.7 & 3.8 \\
\hline Omo Micro Finance Office & 525 & 19 & 29 & I4.3 & 31.8 & 5.9 \\
\hline Technical and Vocational Training Colleges & 525 & 13.3 & 18.5 & 21.9 & 40.2 & 6.1 \\
\hline Wolaita Soddo University & 525 & I8.7 & 22.5 & 25.5 & 28.4 & 26.5 \\
\hline
\end{tabular}

In the local government micro and small enterprises development strategy, ten local government and institutions are identified as stakeholders in supporting the businesses. Thus, the study posed a question to understand business satisfaction by the support given by each local government departments and institutions. Table 7 indicates that Most of the owners/managers 
were not satisfied with the support given by the local government departments, offices, and federal institutions in the local area. These reports from owners/managers tell us that there was big institutional support gap in the local government departments, offices and federal institutions in the area for the performance of the enterprises since most of the respondents dissatisfied or neutral for their support.

Qualitative data from key informants also indicated that the support of local government and institutions for MSMEs was weak. Accordingly, from the total 22 interviewees 17 (77.3\%) indicated that the support given by local institutions were weak, $4(18.2 \%)$ indicated medium and the balance I (4.5) indicated the support was better. According to both quantitative and qualitative data results, the supportive activities of local government and institutions have not been effective. Most of the respondents were reported their dissatisfaction by the support given by local institutions. However, according to extant literature, the supportive activities made by local governments have proven to benefit the development of long-term business towards partners and for MSMEs to take advantage of the opportunities created by local governments.

\subsubsection{Effectiveness of Local Government and Institutions Support in Identified Six Factors}

In order to assess the effectiveness of government support, we examined six factors that are included in the MSEs development strategy document. The factors extracted from local government and institutions support are an institution, working premises, infrastructure, finance, marketing, and management factors, which are external to the firms. The first variable is the institutional factor. Six items related to formal and informal institutions, which were measured on a five-point scale (ranging from $\mathrm{I}=$ strongly disagree to $5=$ strongly agree), were evaluated by the owners/managers of MSMEs. Table 4.59 indicates that $37 \mathrm{I}$ or 70.7 percent out of the total 525 sampled respondents agree or strongly agree that tax levied on their business is not reasonable, 34 or 6.5 percent has no comment, and I20 or 2I.8 percent disagree or strongly disagree by the statement. This response from owners/managers tells us that high tax burden or tax levied on business affected the performance of the businesses.

Concerning administrative burden, 378 or 72 percent agree or strongly agree that administrative burden (i.e., costly company registration and licensing bureaucracy) are a burden to their business, 34 or 6.5 percent are neutral, and II3 or 2I.5 percent disagree or strongly disagree by the statement. The third item in the institutional factor is the laws and regulations of the local government. Regarding this item, 350 or 66.6 percent agree or strongly agree that laws and regulations imposed by local government are not conducive for their business, 59 or II.2 percent are neutral, and the balance II 6 or 22.1 percent disagree or strongly disagree by the statement. Regarding the fourth item, that is information about laws and regulations of local government 367 or $69.9 \%$ of the respondents reported that relevant information about laws and regulations is not easily obtained. Table 8 presented the agreement or disagreement level of the owners/managers regarding the institutional factors as a determinant of the business performance.

Table 8. MSME Owners'/Managers' Opinion on the Institutional Factors

\begin{tabular}{|c|c|c|c|c|c|c|}
\hline \multirow{2}{*}{$\begin{array}{l}\text { Level of Agreement/ } \\
\text { Disagreement }\end{array}$} & \multicolumn{6}{|c|}{ Items } \\
\hline & $\operatorname{InI}(\%)$ & $\operatorname{In} 2(\%)$ & $\begin{array}{l}\text { In3 } \\
(\%)\end{array}$ & $\operatorname{In} 4(\%)$ & $\begin{array}{l}\text { In5 } \\
(\%)\end{array}$ & $\begin{array}{l}\text { In6 } \\
(\%)\end{array}$ \\
\hline S. Disagree & 3.4 & 2.1 & 3.2 & $\mathrm{I} .3$ & 1.0 & 2.7 \\
\hline Disagree & 19.4 & 19.4 & 18.9 & I8.5 & $22 . I$ & 19.0 \\
\hline No comment & 6.5 & 6.5 & II.2 & 10.3 & 8.2 & 6.9 \\
\hline Agree & 37.9 & 47.8 & $45 . I$ & 46.3 & 40.0 & 43.8 \\
\hline S. Agree & 32.8 & 24.2 & 21.5 & 23.6 & 28.8 & 27.6 \\
\hline Mean & 3.77 & 3.73 & 3.63 & 3.72 & 3.73 & 3.75 \\
\hline Mode & 4.00 & 4.00 & 4.00 & 4.00 & 4.00 & 4.00 \\
\hline Std. Deviation & I.I95 & 1.095 & I.I I2 & 1.060 & I.I27 & I.I33 \\
\hline
\end{tabular}

Inst $\mathrm{I}=$ High taxes (Tax levied on my business is not reasonable); In2 = Administrative burden (Costly company registration and licensing bureaucracy are burdens to my business ); In3 = Laws and regulations imposed by local government are not conducive for business; In4= Information about laws and regulations relevant to my business is not easily obtained; In5 $=$ Corruption (unofficial payment request during obtaining different services affects my business and In6= Unfair competition affects my business 
The fifth and sixth items in an institutional variable are about corruption and unfair competition, which are informal institutional factors. Corruption by public officials can be a major administrative and financial burden on firms' performance. It creates an unfavorable business environment by declining operational efficiency and raising the costs and risks associated with running a business. Owners/managers of MSMEs were asked to know their perception about the impact of corruption or unofficial payment request during obtaining different services on their businesses. As it can be seen from the Table 8 above from 525 respondents $36 \mathrm{I}$ or 68.8 percent agree or strongly agree that unofficial payment affected their performance, 43 or 8.2 percent were undecided and the balance I2I or 23.I percent disagree or strongly disagree by the statement. Concerning competition, 375 or 71.4 percent from the total sampled 525 owners/manager agree or strongly agree that unfair competition as a burden for their business performance, 36 or 6.9 percent neutral, while II4 or 2I.7 percent disagree or strongly disagree by the statement (Table 8).

The second MSMEs determinant variable included as an external factor is working premises. This study identified three items from the literature that are believed to represent the working premises factor as a determinant in business performance. The first item is the presence of own premises. Concerning the presence of own working premises, 340 or 64.8 per cent from the total sampled 525 owners/manager agree or strongly agree that absence of own premises as a burden for their business performance, 30 or 5.7 percent neutral, while 155 or 29.5 percent disagree or strongly disagree with the statement (Table 9). The second item in the working premises variable is the convenience of the current working place. As it was indicated in Table 9, 317 or 60.4 percent agree or strongly agree that current working place is not convenient for the business, 3I or 5.9 percent are neutral, while the balance 177 or 32.8 percent disagree or strongly disagree by the statement. Concerning house rent, 293 or 55.8 percent from the total sampled 525 owners/manager agree or strongly agree that house rent is too high to their business, 32 or 6 .I percent neutral, while 200 or 38 .I percent disagree or strongly disagree by the statement. This implies that the absence of own premises is the main working premises factor that is limiting the performance of small enterprises in the administrative towns as it affects with a greater mean value of $3.5 \mathrm{I}$ of the respondent's agreement.

Table 9. MSME Owners'/Managers' Opinion on the Working Premises Factors

\begin{tabular}{|c|c|c|c|c|c|c|}
\hline \multirow{3}{*}{$\begin{array}{c}\text { Level of Agreement/ } \\
\text { Disagreement }\end{array}$} & \multicolumn{6}{|c|}{ Items } \\
\hline & \multicolumn{2}{|c|}{ WPI } & \multicolumn{2}{|c|}{ WP2 } & \multicolumn{2}{|c|}{ WP3 } \\
\hline & $f$ & $\%$ & $f$ & $\%$ & $\bar{f}$ & $\%$ \\
\hline Strongly Disagree & $3 I$ & 5.9 & 46 & 8.8 & 70 & 13.3 \\
\hline Disagree & $\mathrm{I} 24$ & 23.6 & I3I & 25.0 & $\mathrm{I} 30$ & 24.8 \\
\hline No comment & 30 & 5.7 & $3 I$ & 5.9 & 32 & 6.1 \\
\hline Agree & 224 & 42.7 & I94 & 37.0 & 180 & 34.3 \\
\hline Strongly Agree & II6 & 22.1 & $\mathrm{I} 23$ & 23.4 & II3 & $2 \mathrm{I} .5$ \\
\hline Mean & \multicolumn{2}{|c|}{$3.5 \mathrm{I}$} & \multicolumn{2}{|c|}{$3.4 \mathrm{I}$} & \multicolumn{2}{|c|}{3.26} \\
\hline Mode & \multicolumn{2}{|c|}{4.00} & \multicolumn{2}{|c|}{4.00} & \multicolumn{2}{|c|}{4.00} \\
\hline Standard Deviation & \multicolumn{2}{|c|}{ I.233 } & \multicolumn{2}{|c|}{ I.3I9 } & \multicolumn{2}{|c|}{ I.386 } \\
\hline
\end{tabular}

Note $\mathrm{f}=$ Frequency; $\%=$ Percent; WPI $=$ There is the absence of own premises; Wp2 $=$ Current working place is not convenient, and $\mathrm{Wp} 3=$ House rent is too high for my business

The third variable in the external factor is infrastructure. Table 10 shows the perception of owners/managers concerning infrastructural factors. This study identified five items from the literature that are believed to represent the infrastructural factor as a determinant in business performance. The first item in infrastructure variable is about the power supply. According to the data, from the total sampled 525 MSME owners/managers, 39I or 74.5 percent agree or strongly agree that absence of power and power interruption as a problem for the performance of the business, 56 or 10.7 percent neutral, while the balance 78 or I4.8 percent disagree or strongly disagree the statement. The second item in the infrastructural factor is about the supply of water. Concerning this item, 347 or 66.I percent agree or strongly agree that insufficient and interrupted the supply of water as an obstacle for the performance of the business, 83 or I5.8 percent neutral, while the balance 95 or I8.I percent disagree or strongly disagree the statement. The third item in the infrastructural factor is about business development services. Concerning this item, 35I or 66.8 percent agree or strongly agree that lack of business development services as an obstacle for the performance of the business, 89 or I7.0 percent neutral, while the balance 85 or I6.2 percent disagree or strongly disagree the statement.

The fourth item in the infrastructural factor is about transportation services. Concerning this item, 322 or 6I.3 percent agree or strongly agree that lack of quick and sufficient transportation service as an obstacle for the performance of the 
business, 62 or II.8 percent neutral, while the balance I4I or 26.9 percent disagree or strongly disagree the statement. The fifth item in infrastructural factor is about the dry waste and sewerage system. Regarding this item, 340 or 64.8 percent agree or strongly agree that lack of appropriate dry waste collection and sewerage system as an obstacle for the performance of the business, 79 or I5 percent neutral, while the balance I05 or 20 percent disagree or strongly disagree the statement.

Table I0. MSME Owners'/Managers' Opinion on the Infrastructure Factors

\begin{tabular}{|c|c|c|c|c|c|}
\hline \multirow{2}{*}{$\begin{array}{c}\text { Level of Agreement/ } \\
\text { Disagreement }\end{array}$} & \multicolumn{5}{|c|}{ Items } \\
\hline & InfraI (\%) & Infra2 (\%) & $\begin{array}{c}\text { Infra3 } \\
(\%) \\
\end{array}$ & $\begin{array}{c}\text { Infra4 } \\
(\%)\end{array}$ & Infra5 (\%) \\
\hline Strongly Disagree & 3.4 & 5.0 & 2.3 & 6.3 & 4.4 \\
\hline Disagree & II.4 & I3.I & 13.9 & 20.6 & I5.6 \\
\hline No comment & 10.7 & I5.8 & 17.0 & II.8 & $\mathrm{I} 5.0$ \\
\hline Agree & 48.6 & 49.3 & 49.3 & 40.0 & 44.2 \\
\hline Strongly Agree & 25.9 & 16.8 & 17.5 & 21.3 & 20.6 \\
\hline Mean & 3.82 & 3.60 & 3.66 & 3.49 & 3.60 \\
\hline Mode & 4.00 & 4.00 & 4.00 & 4.00 & 4.00 \\
\hline Standard Deviation & I.049 & 1.067 & .996 & 1.212 & I.II8 \\
\hline
\end{tabular}

Note: Infra I = There is the absence of power and power interruptions); Infra2= Supply of water is insufficient and interrupted; Infra3 $=$ There is lack of business development services; Infra4= There is lack of sufficient and quick transportation service, and Infra $5=$ There is lack of appropriate dry waste and sewerage system

The fourth variable in the external factor is marketing variable. Table II presents the perception of owners/managers concerning marketing factors. This study identified seven items from the literature that are believed to represent the marketing factor as a determinant in business performance.

The first item in marketing variable is about the market adequacy for the product or service of the business. From the total sampled 525 MSME owners/managers, 396 or 75.4 per cent were agree or strongly agree that inadequate market for the product or service of the business as a problem for the performance of the business, 3I or 5.9 percent neutral, while the balance 98 or I8.7 percent disagree or strongly disagree with the statement.

The second item in marketing variable is about searching a new market for the product or service. Concerning this item, 385 or 73.4 percent agree or strongly agree that difficulty of searching new market for the product or service as an obstacle for the performance of the business, 29 or 5.5 percent neutral, while the balance III or 2I.I percent disagree or strongly disagree the statement. The third item in marketing variable is about the quality of the product or service of the business. Concerning this item, 246 or 46.9 percent agree or strongly agree that poor quality of the product or service as an obstacle for the performance of the business, 89 or 17.0 percent neutral, while the balance 190 or 36.2 percent disagree or strongly disagree the statement.

The fourth item in marketing variable is about the market network for the product or service of the business. Regarding this item, 3II or 59.2 percent agree or strongly agree that difficulty in establishing a new market network for the product or service as an obstacle for the performance of the business, 83 or I5.8 percent neutral, while the balance I3I or 25 percent disagree or strongly disagree the statement. The fifth item in marketing variable is about market information. Regarding this item, 33I or 63.Ipercent agree or strongly agree that problem in accessibility of market information as an obstacle for the performance of the business, 68 or I3 percent neutral, while the balance 126 or 24 percent disagree or strongly disagree the statement.

The sixth item in marketing variable is about promotion to attract potential users. Regarding this item, 320 or 60.9 percent agree or strongly agree that problem in promotion attract potential users as an obstacle for the performance of the business, 68 or 13 percent neutral, while the balance 137 or 26.I percent disagree or strongly disagree the statement. The seventh item in marketing variable is about customers' relationship and handling. Regarding this item, 213 or 40.6 percent agree or strongly agree that problem in customers' relationship and handling as an obstacle for the performance of the business, 54 or I0.3 percent neutral, while the balance 258 or 49 .I percent disagree or strongly disagree the statement 
Table II. MSME Owners'/Managers' Opinion on the Marketing Factors

\begin{tabular}{|c|c|c|c|c|c|c|c|}
\hline \multirow{2}{*}{$\begin{array}{c}\text { Level of Agreement/ } \\
\text { Disagreement }\end{array}$} & \multicolumn{7}{|c|}{ Items } \\
\hline & $\mathrm{MI}(\%)$ & M2 (\%) & M3 (\%) & M4 (\%) & M5 (\%) & M6 (\%) & M7 (\%) \\
\hline Strongly Disagree & 4.0 & 3.2 & 6.7 & 4.0 & 3.0 & 4.8 & I I.4 \\
\hline Disagree & I4.7 & 17.9 & 29.5 & 21.0 & 21.0 & 21.3 & 37.7 \\
\hline No comment & 5.9 & 5.5 & 17.0 & I5.8 & 13.0 & 13.0 & 10.3 \\
\hline Agree & 56.0 & 53.0 & 37.0 & 43.8 & 49.0 & 43.4 & 27.8 \\
\hline Strongly Agree & 19.4 & 20.4 & 9.9 & I5.4 & I4.I & 17.5 & 12.8 \\
\hline Mean & 3.72 & 3.69 & 3.14 & 3.46 & 3.50 & 3.48 & 2.93 \\
\hline Mode & 4.00 & 4.00 & 4.00 & 4.00 & 4.00 & 4.00 & 2.00 \\
\hline Standard Deviation & I.06I & I.084 & I.I45 & I.I04 & 1.066 & I.I47 & 1.273 \\
\hline
\end{tabular}

Note: $\mathrm{MI}=$ The market for my product/service is inadequate; $\mathrm{M} 2=$ Searching new market is too difficult; $\mathrm{M} 3=\mathrm{My}$ products are Poor in quality for the market; M4= Establishing market network is difficult for my product; M5= There is a problem in market information; M6= Promotion to attract potential users is lacking, and M7 = Customer relationship and handling is poor in my firm

The fifth variable in external factor is financial variable. Table 4.63 presents the perception of owners/managers concerning financial variables. This study identified six items from the literature that are believed to represent the financial variable as a determinant in business performance.

The first item in the financial variable is about the credit institution. From the total sampled $525 \mathrm{MSME}$ owners/managers, 37I or 70.6 percent agreed or strongly agree that absence or inadequacy of credit institutions as a problem for the performance of the business, 48 or 9.I percent was neutral. While the balance 106 or 20.2 percent disagree or strongly disagree with the statement. The second item in the financial variable is about searching for access to credit institutions. Concerning this item, 379 or 72.2 percent agree or strongly agree that lack of access to credit institutions as an obstacle for the performance of the business, 55 or I0.5 percent neutral, while the balance 9I or I7.3 percent disagree or strongly disagree the statement. The third item in the financial variable is about working capital. Concerning this item, 402 or 76.6 percent agree or strongly agree that shortage of working capital as an obstacle for the performance of the business, 57 or I0.9 percent neutral, while the balance 66 or 12.6 percent disagree or strongly disagree the statement.

The fourth item in the financial variable is about collateral requirement from lending institutions. Regarding this item, 416 or 79.3 percent agree or strongly agree that high collateral requirement from lending institutions as an obstacle for the performance of the business, 46 or 8.8 percent neutral, while the balance 63 or 12 percent disagree or strongly disagree the statement. The fifth item in the financial variable is about the interest rate of lending institutions. Regarding this item, 407 or 77.5 percent agree or strongly agree that high-interest rate by lending institutions as an obstacle for the performance of the business, 48 or 9.I percent neutral, while the balance 70 or 13.4 percent disagree or strongly disagree the statement. The sixth item in the financial variable is about loan application procedures. Regarding this item, 399 or 76 percent agree or strongly agree that complicated loan application procedure as an obstacle for the performance of the business, 38 or 7.2 percent neutral, while the balance 88 or 16.8 percent disagree or strongly disagree the statement.

Table I2. MSME Owners'/Managers' Opinion on the Financial Factors

\begin{tabular}{|c|c|c|c|c|c|c|}
\hline \multirow{2}{*}{$\begin{array}{c}\text { Level of Agreement/ } \\
\text { Disagreement }\end{array}$} & \multicolumn{6}{|c|}{ Items } \\
\hline & FI (\%) & F2 (\%) & F3 (\%) & $\mathrm{F} 4(\%)$ & F5 (\%) & F6 (\%) \\
\hline Strongly Disagree & 2.7 & $\mathrm{I} .7$ & 1.7 & 2.1 & 2.5 & 4.6 \\
\hline Disagree & 17.5 & 15.6 & 10.9 & 9.9 & 10.9 & $\mathrm{I} 2.2$ \\
\hline No comment & 9.1 & 10.5 & 10.9 & 8.8 & 9.1 & 7.2 \\
\hline Agree & 43.6 & 46.3 & 48.4 & 48.4 & 45.1 & 43.2 \\
\hline Strongly Agree & 27.0 & 25.9 & 28.2 & 30.9 & 32.4 & 32.8 \\
\hline Mean & 3.75 & 3.79 & 3.90 & 3.96 & 3.94 & 3.87 \\
\hline Mode & 4.00 & 4.00 & 4.00 & 4.00 & 4.00 & 4.00 \\
\hline Standard Deviation & I.I I4 & I.049 & .986 & $.99 \mathrm{I}$ & $\mathrm{I} .035$ & I.I34 \\
\hline
\end{tabular}


Note: FI= Absence or inadequacy of credit institution; F2 = Lack of access to credit institution; F3= Shortage of working capital; F4= High collateral requirement from lending institutions; F5= High-interest rate by a lending institution; and F6= Complicated Loan application procedure

The sixth variable in external factor is management variable. Table 4.64 presents the perception of owners/managers concerning management variables. This study identified six items from the literature that are believed to represent the management variable as a determinant in business performance.

The first item in the management variable is about the division of duties among members. From the total sampled 525 MSME owners/managers, 95 or I8.I percent agreed or strongly agree that lack of clear division of duties among members in their firm as a problem for the performance of the business, 28 or 5.3 percent neutral, while the balance 402 or 76.5 percent disagree or strongly disagree the statement. The second item in the management variable is about communication in the firm. Concerning this item, 79 or I5 percent agree or strongly agree that Poor organization and ineffective communication as an obstacle for the performance of the business, 3I or 5.9 percent neutral, while the balance 4 I5 or 79 percent disagree or strongly disagree the statement.

The third item in the management variable is about the selection of business partners. Concerning this item, 93 or I7.7 percent agree or strongly agree that poor selection of business partners as an obstacle for the performance of the business, 52 or 9.9 percent neutral, while the balance 380 or 72.4 percent disagree or strongly disagree the statement. The fourth item in the management variable is about well-trained and experienced employees. Regarding this item, I58 or 30.I percent agree or strongly agree that lack of well-trained and experienced employees as an obstacle for the performance of the business, 40 or 7.6 percent neutral, while the balance 327 or 62.3 percent disagree or strongly disagree the statement.

The fifth item in the management variable is about training. Regarding this item, 172 or 32.7 percent agree or strongly agree that lack of low cost and accessible training facilities as an obstacle for the performance of the business, 37 or 7 percent neutral, while the balance 3 I 6 or 60.2 percent disagree or strongly disagree the statement. The sixth item in the management variable is about financial, human and material management. Regarding this item, I46 or 27.8 percent agree or strongly agree that lack of financial, human and material management as an obstacle for the performance of the business, 42 or 8 percent neutral, while the balance 337 or 64.2 percent disagree or strongly disagree the statement.

Table 13. MSME Owners'/Managers' Opinion on the Management Factors

\begin{tabular}{lcccccc}
\hline $\begin{array}{c}\text { Level of Agreement/ } \\
\text { Disagreement }\end{array}$ & $\begin{array}{c}\text { MngI } \\
(\%)\end{array}$ & $\begin{array}{c}\text { Mng2 } \\
(\%)\end{array}$ & Mng3 (\%) & $\begin{array}{c}\text { Mng4 } \\
(\%)\end{array}$ & $\begin{array}{c}\text { Mng5 } \\
(\%)\end{array}$ & $\begin{array}{c}\text { Mng6 } \\
(\%)\end{array}$ \\
\hline Strongly Disagree & 35.0 & 21.5 & 30.7 & 27.6 & 26.1 & 27.4 \\
\hline Disagree & 41.5 & 57.5 & 41.7 & 34.7 & 34.1 & 36.8 \\
\hline No comment & 5.3 & 5.9 & 9.9 & 7.6 & 7.0 & 8.0 \\
\hline Agree & 15.2 & 13.3 & 15.6 & 25.5 & 27.4 & 22.7 \\
\hline Strongly Agree & 2.9 & 1.7 & 2.1 & 2.6 & 5.3 & 5.1 \\
\hline Mean & 2.09 & 2.15 & 2.17 & 2.45 & 2.52 & $2.4 \mathrm{I}$ \\
\hline Mode & 2.00 & 2.00 & 2.00 & 2.00 & 2.00 & 2.00 \\
\hline Standard Deviation & 1.124 & .965 & 1.092 & 1.260 & 1.282 & 1.247 \\
\hline
\end{tabular}

Note MngI= There is no clear division of duties among members in my firm; Mng2= There are Poor organization and ineffective communication; Mng3 = The selection of business partners is poor; Mng4=

There is a lack of well trained and experienced employees; Mng5= There is a lack of low cost and accessible training facilities; and Mng6 $=$ There is a lack of financial, human and material management

Based on the summary of descriptive statistics presented in Table I4 with respect to external factors (enabling business environment) the mean value ranges between 3.40 to 3.90 except for management factor that most of the respondents are agreed with the statements that the factors influence their firm performance with standard deviation 0.70 to I.I5. All of the factors show high sampling adequacy with KMO value greater than 0.75 . The Cronbach's alpha value for all items taken together yields greater than 0.7 indicating that the items of all the variables are reliable and can be retained as a measure of a firm's performance. 
Table I4. Summary of Descriptive Statistics of External Factors

\begin{tabular}{lccccccc}
\hline Factors & $\mathrm{N}$ & Mean & St Dev & Min & Max & KMO & Cronbach's alpha \\
\hline Institutional & 525 & 3.72 & 0.858 & $\mathrm{I}$ & 5 & 0.825 & 0.858 \\
\hline Infrastructure & 525 & 3.64 & 0.743 & $\mathrm{I}$ & 5 & 0.773 & $0.7 \mathrm{I0}$ \\
\hline Working Premises & 525 & 3.40 & $\mathrm{I} . \mathrm{II}$ & $\mathrm{I}$ & 5 & $0.7 \mathrm{II}$ & 0.803 \\
\hline Finance & 525 & 3.87 & 0.825 & $\mathrm{I}$ & 5 & 0.843 & 0.874 \\
\hline Marketing Linkage & 525 & 3.42 & 0.749 & $\mathrm{I}$ & 5 & 0.798 & 0.789 \\
\hline Management & 525 & 2.30 & 0.930 & $\mathrm{I}$ & 5 & 0.867 & 0.885 \\
\hline
\end{tabular}

Qualitative data from key informants interview, also fully verify the survey finding as follows: $55.5 \%$ of respondents from participants of MSMEs put the responsibility directly on the poor electric power supply and tax burden equally, $50 \%$ blamed limitation of market linkages, and 3I.8 blamed the escalating cost of raw materials. The key interview result also shows $22.7 \%$ lack of working and selling space as a problem, I8.2\% reported corruption and lack of good governance, I3.6\% blamed access to finance, shortage of inputs and infrastructure, and $4.5 \%$ held poor government support as problems in their performance. The MoUDH annual report of (2018) also points out a similar result that the achievement of the goals targeted for MSEs was low due to the weak support of stakeholders. The report indicated that support given based on the development stage of the enterprises, equitable provision of working premises; facilitating credit access and creating market linkages for the enterprises were low at the country level. As it is identified both in quantitative and qualitative data, it is clear from the results that problems related to electric power supply, tax burden, limitation of market linkages and the escalating cost of raw materials in the local market were highly critical and major contributors to low performance of the firms. All of the challenges identified are from external factors due to ineffective local government and institutions support.

This finding was in line with the Ministry of Urban Development and Housing 2018 annual GTP performance report in that the support given to MSEs by the government and institutions was weak. The report indicated that provision of working and selling places, provision of credit, and creation of market linkages for the enterprises by the stakeholders of the local governments and institutions were not satisfactory to achieve the goals of GTP II. The interpretation from both findings is that MSMEs were not satisfied with the support given or provided by local governments and institutions and the favorability of the business environment is low. Therefore, any effort to improve the investment situation and performance of the economic activities cannot be effective unless local governments and institutions provide necessary effective support and make the business environment suitable for the investment and performance of the businesses. Overall, as compared to what is required in urban development and industrial development policies and strategies of the nation, the support provided by the local governments and institutions is not satisfactory to attract investment to the local area and enhance the performance of the existing firms.

\section{Conclusion and Recommendation \\ 5.I Conclusion}

The study generated empirical evidence that indicates how the support and guidance of local government are necessary for small businesses performance and their competitiveness. Overall, as a country, it is clearly shown that the government has exerted considerable efforts in creating a conducive environment for firms to invest and function in the economy. The government efforts were evidently manifested by not only formulating and promulgating different policies and strategies but also designing and implementing various support instruments to help enterprises meet the dynamic socio-economic situations of the country by the local government. Based on these general national policies and strategies direction, the study examined the support and guidance of local government institutions whether they support and guide the businesses in the administrative towns according to crafted strategy documents.

The result indicated a gap in the support and guidance of the local government. Most of the respondents show their dissatisfaction by the support and local business environment in enhancing their performance. There is a big gap between the support envisioned in micro and small enterprises development strategy and the support provided to MSMEs by local government and institutions. These findings confirm that the lack of supply of infrastructure, working premises, finance, market linkages, and other government support based on their growth level contributed significantly to the low performance of the sector. 


\subsection{Recommendations}

Recently, Ethiopia as a nation in general and Wolaita part of it specifically, face a number of challenges that can only be met if they have innovative, well-educated and entrepreneurial citizens who, whatever their profession, have the spirit and curiosity to think in new ways, and the courage to meet and adapt to the challenges facing them. Furthermore, a dynamic economy, which is innovative and able to create jobs that are needed, requires a greater number of young people who are willing and able to become entrepreneurs. In another word, the nation needs a large number of younger people who will launch and successfully develop their own ventures, or social organizations in which they work or who will become innovators in the wider organizations in which they work. This needs the support of both the local and federal governments in shaping young people's attitudes, skills, and culture. To do this the following recommendations are forwarded for local governments and other stakeholders.

Creating Access to finance:- Those enterprises, which make use of the bank and another local financing, are found out to have a higher scale of operation based on extant literature and other countries experience. However, in our case, MSMEs are using neither government banks (except Micro Finance Institutions) nor private banks. Adequate provision of finance should be implemented properly, which is one of the key elements of business support packages. Ways need to be created to guarantee that MSMEs benefit from the services of formal Commercial banks, Development bank, and microfinance institutions in shortening the long procedures needed in the reasonable interest rate. The government should also improve the capacity of microfinance institutions to enable them to avail adequate loan to small businesses.

Creating market linkages:- Creating a market linkage is one of the support packages by the government to enhance firms' performance. However, lack of access to the market is one of the factors that determine the performance of enterprises in the local business environment dimension. Therefore, local government in collaboration with other stakeholders need to identify business areas where MSMEs can successfully participate as a supplier, intermediate producer, and distributor and developing mechanisms whereby product quality and unit costs are improved as a result of integrating MSMEs in those identified business activities. By giving training and other business support the local government creates enabling situation to the firms to participate in issues like outsourcing, subcontracting, out growers, etc. linkages with larger firms and export sector.

Provision of Working Premises: - Major problems like the sufficiency of working premises, its suitability, and others that MSMEs in administrative towns of Wolaita Zone need to be addressed by prioritizing them in accordance of their severity as well as the availability of resources to run the operation. MSE development agency and municipal services should undertake a detailed study on the suitability of the location and the sufficiency of work premise size along with nature and type of business before constructing the premises for MSE.

\section{References}

Assefa, B., Zerfu, A., \& Tekle, B. (2014). Identifying Key Success Factors and Constraints of Ethiopia’s MSE Development: An Exploratory Research. EDRI Research Report I8. Addis Ababa: Ethiopian: Ethiopian Development Research Institute.

Brhane, T. (2014). "Access to Finance for Micro and Small Enterprises in Debre Markos Town Ethiopia”. Global Journal of Current Research, 2 (2), 36-46.

Central Statistical Agency (2012). Statistical Report On the 20I2Large and Medium Scale Manufacturing and Electricity Industries Survey, Statistical Bulletin 53I August, 2012, Addis Ababa

Central Statistical Agency (2007).Compilation of Economic Statistics in Ethiopia, Addis Ababa

Dardak, E. E. (2007). The Development of Agricultural-Based Small Urban Areas to Promote Rural Development, Doctoral dissertation, Ritsumeikan Asia Pacific University.

Dickovick, J.T. and Tegegne G. (2010). Comparative Assessment of Decentralization in Africa: Ethiopia desk study, USAID Series. Available at: http-www.usaid.gov-our_work-democracy_and_governance-publications-pdfsethiopia_desk_study [accessed 29 January 2018].

Fatoki O. (2012). "The Impact of Networking on Access to Debt Finance and Performance of Small and Medium Enterprises in South Africa”. Journal of Social Sciences; 32(2): I2I-I3I.

Federal Micro and Small Enterprises Development Agency Establishment Council of Ministers (201 I: 5766). Federal Negarit Gazeta of the federal democratic Republic of Ethiopia. Regulation No. 20I/20II, Addis Ababa.

Fikadu, G. F. (2015). "Determinants of Micro and Small Enterprises Growth in Ethiopia: The Case of Nekemte Town of Oromia Region, Ethiopia”. European Journal of Business and Management Vol.7, No.13, 2015

Garoma, B. F. (20I2). Determinants of microenterprise success in the urban informal sector of Addis Ababa: A multidimensional analysis, Ph.D. Dissertation, Erasmus University Rotterdam, Netherlands.

Ibrahim NI, Masiud A. Moderating role of entrepreneurial orientation on the relationship between entrepreneurial skills, environmental factors, and entrepreneurial intention: A PLS approach. Management Science Letters 2016; 6(3): 225-236. http://doi.org/I0.5267/j.msl.2016.I.005

Kothari, C. R. 2004. Research Methodology: Methods and Techniques, New Delhi, New Age International (P) Ltd. 
Legesse, L., B. (2014). Factors Hindering Industrialization of Ethiopia: The Case of Medium and Large Scale Manufacturing Industries in Major Industrial Zones of Ethiopia. Ph.D. Dissertation, Ethiopian Civil Service University, Addis Ababa.

Leza, T., Rajan, S., \& Kuma, B. (2017). "Determinants of product diversification among micro and small enterprises in Wolaita zone, Ethiopia: An econometric analysis", Global Journal of Human-Social Science Research.

Liedholm, C. (2002). "Small firm dynamics: Evidence from Africa and Latin America”, Small Business Economics, I8:227242.

Meheret, A. (2007). A Rapid Assessment of Woreda Decentralization in Ethiopia, Decentralization in Ethiopia. In: Taye Assefa and Tegegne Gebre-Egziabher, ed.2007. Decentralization in Ethiopia. Addis Ababa: Forum for Social Studies, Ch2.

Ministry of Urban Development and Construction of Ethiopia (2013). Survey on Micro and Small Enterprises (MSEs) in Selected Major Cities of Ethiopia, Addis Ababa.

Quy NH. Legislative Policy in Support of Vietnam SMEs: “Analysis and Propositions”. International Journal of Economics and Finance 2016; 8(2): 226-233. http://doi.org/I0.5539/ijef.v8n2p226

PSCAP Report (2008). Ethiopia Public Sector Capacity Building Program Support Project: Mid-Term Review Aide Memoire, Ethiopia.

Roxas, H. B., Lindsay, V., Ashill, N., \& Victorio, A. (2009). Do institutions matter to the strategic posture and performance of SMEs? Lessons from an emerging economy. In Proceedings of the 22nd Annual Conference of the Small Enterprise Association of Australia and New Zealand (SEAANZ 2009). Small Enterprise Association of Australia and New Zealand.

Shariff MNM, Peou C, Ali J. (2010). "Moderating Effect of Government Policy on Entrepreneurship and Growth Performance of Small-Medium Enterprises in Cambodia”. International Journal of Business and Management Science 20I0; 3(I): 57-72.

Tantu, A. T., Gamebo, T. D., Sheno, B. K., \& Kabalo, M. Y. (2017). Household food insecurity and associated factors among households in Wolaita Sodo town, 2015. Agriculture \& Food Security, 6(I), I9.

Tsegaye, T. ( 2006). Evaluation of the Operation and Performance of Ethnic Decentralization System in Ethiopia: A Case Study of Guraghe People, I999-2000. Ethiopia: Addis Ababa University Press.

Wolaita Zone Finance and Economic Development Department (2018). Wolaita Zone Finance and Economic Development Department Data Collection, Organization and Dissemination Work Process Annual Abstract, Wolaita Soddo, SNNPRS, Ethiopia

Wolaita Zone Finance and Economic Development Department (2017). Wolaita Zone Finance and Economic Development Department Data Collection, Organization and Dissemination Work Process Annual Abstract, Wolaita Soddo, SNNPRS, Ethiopia

Wolaita Zone Youth and Sports Department (2017). Wolaita Zone Youth and Sports Department Annual Report, Wolaita Soddo, SNNPRS, Ethiopia

Zemelak, A. (20II). Law, Democracy \& Development / Vol I5 (20II), ISSN: 2077-4907. Available at: http://www.ldd.org.za/images/stories/Ready_for_publication/zemelak-new.pdf [accessed 28 March 2019].

\section{Copyrights}

Copyright for this article is retained by the author(s), with first publication rights granted to the journal. This is an open-access article distributed under the terms and conditions of the Creative Commons Attribution license (http://creativecommons.org/licenses/by/4.0/). 